\title{
$15: 39593369-39583132$
}

National Cancer Institute

\section{Source}

National Cancer Institute. 15: 39593369-39583132. NCI Thesaurus. Code C45022.

Physical location of LTK_Gene 